\title{
PELATIHAN RANCANG BANGUN PERALATAN ELEKTRONIK MENGGUNAKAN RASPBERRY PI UNTUK SISWA
}

\author{
${ }^{1}$ Mohammad Fadly Syah Putra, ${ }^{2}$ Sarah Purnamawati, ${ }^{3}$ Ainul Hizriadi \\ ${ }^{123}$ Program Studi S1 Teknologi Informasi \\ Fakultas Ilmu Komputer dan Teknologi Informasi \\ Universitas Sumatera Utara \\ E-mail: fadlysyah@.usu.ac.id | sarah_purnamawati@usu.ac.id | ainul.hizriadi@usu.ac.id
}

\begin{abstract}
Abstrak
Perkembangan perangkat elektronik sedemikan berkembangnya sehingga mencapai ukuran yang semakin kecil, ikut diimbangi dengan meningkatnya pemanfaatan perangkat tersebut dalam kurikulum pendidikan di perguruan tinggi. Bahkan, di wilayah negara lain, kurikulum pendidikan yang mengajarkan tentang rancang bangun perangkat elektronik telah dimulai di jenjang pendidikan sekolah dasar. Saat ini di Indonesia, pengajaran tentang rancang bangun perangkat elektronik di jenjang pendidikan hanya di beberapa sekolah tertentu saja. Namun, minat peserta didik terhadap bidang ini semakin meningkat, yang dapat dilihat dari semakin banyaknya kontes robotika di daerah maupun dalam skala nasional. Potensi positif yang dapat diberikan oleh teknologi ini akan dapat berperan di masa yang akan datang, dimana peserta didik nantinya diharapkan mampu untuk menciptakan perangkat elektronik tepat guna, dan tidak hanya menjadi konsumen produk-produk perangkat elektronik yang diproduksi dari luar. Selain dibuat menjadi sebuah robot, contoh lain pemanfaatan perangkat elektronik di masyarakat adalah pembuatan pengendali motor listrik, saklar yang bisa dikendalikan jarak jauh, pengendali lampu, bahkan dapat menjadi sebuah komputer dengan ukuran kecil. Di kurikulum perguruan tinggi, perangkat elektronik yang dipelajari adalah dari sisi sebagai mikrokontroler, yaitu sebuah komponen berbentuk chip yang mampu melakukan komputasi fungsional. Di kurikulum pendidikan dasar dan menengah, perangkat elektronik yang diajarkan lebih mengarah kepada kemampuan siswa menggunakan logika untuk memerintahkan perangkat tersebut mengerjakan pekerjaan tertentu. Salah satu media yang sering dimanfaatkan untuk penelitian, permainan, dan juga pendidikan rancang bangun perangkat elektronik adalah Raspberry Pi. Alat ini dapat berfungsi sebagai mikrokontroler ataupun sebagai Personal Computer (PC) berukuran kecil. Selain cukup mudah mendapatkannya, harganya juga cukup murah.
\end{abstract}

Kata kunci : Raspberry Pi, Peralatan Elektronik.

\section{PENDAHULUAN}

engetahuan tentang rancang bangun
perangkat elektronik yang dapat
berfungsi mengerjakan pekerjaan tertentu semakin berkembang dengan adanya produk Raspberry Pi di pasaran. Tingginya pemanfaatan produk ini untuk penelitian di bidang teknologi komputer, ikut diiringi juga dengan semakin tingginya minat untuk mengenalkannya kepada peserta didik sejak awal untuk mengikuti perkembangan teknologi saat ini dan di masa yang akan datang. Melalui program Pengabdian Kepada
Masyarakat (PKM) yaitu Pelatihan Rancang Bangun Perangkat Elektronik Menggunakan Raspberry Pi untuk Siswa ini, diharapkan mampu mengisi kekosongan akibat belum semua daerah maupun sekolah mengajarkan materi ini dalam kurikulumnya. Program Pengabdian Kepada Masyarakat ini dilaksanakan pada sekolah yaitu SMK IT Marinah Al-Hidayah di Medan, dan juga SMK Mandiri dari Yayasan Pendidikan Siap Mandiri.

Sasaran program ini adalah seluruh elemen sekolah terutama para siswa di sekolah dan sebagian guru. SMK IT Marinah Al-Hidayah adalah sebuah SMK Swasta yang 
Fadly Syahputra, M. et al. Pelatihan Rancang Bangun Peralatan Elektronik...

berada di Jln. Panglima Denai Kota Medan, yang memiliki jumlah siswa sebanyak 80 siswa yang terbagi menjadi 5 jurusan, dan juga guru sebanyak 20 orang. SMK IT Marinah Al-Hidayah memiliki fasilitas komputer yang cukup baik dengan jumlah laboratorium komputer sebanyak 2 (dua) ruangan dengan total 30 unit computer. Sedangkan SMK Mandiri adalah SMK dengan beberapa jurusan komputer dengan jumlah anak sebanyak 1000, dan 3 buah laboratorium komputer.

Akan tetapi kurikulum pendidikan yang ada di SMK IT Marinah Al-Hidayah dan SMK Mandiri belum mencakup materi tentang rancang bangun perangkat elektronik. Kendala yang dihadapi adalah ketersedian materi untuk pembelajaran dalam menggunakan dan memprogram perangkat elektronik komputer yang telah dirancang bangun.

Yang dapat menjadi penentu keberhasilan pelaksanaan program ini di sekolah adalah terbukanya wawasan mereka tentang adanya teknologi ini yang diharapkan mendorong rasa keingintahuan untuk mempelajarinya. Kemudian, yang paling penting adalah keinginan dari seluruh elemen sekolah untuk mendorong minat siswa untuk berkreatifitas memanfaatkan alat praktek yang ada untuk mengembangkan pengetahuan mereka tentang rancang bangun perangkat elektronik komputer dan pemrogramannya

\section{IDENTIFIKASI MASALAH}

Mitra merupakan SMK yang berada di Kecamatan Medan Denai, dan SMK Mandiri di Percut Sei Tuan. Berdasarkan pengamatan yang dituangkan dalam analisis situasi serta komunikasi yang kami lakukan kepada guru dan kepala sekolah di SMK IT Marinah AlHidayah dan SMK Mandiri, maka permasalahan timbul akibat dari adanya keterbatasan kemampuan sekolah untuk mengajarkan tentang teknologi ini. Namun, ada keinginan para guru untuk menambah pengetahuan siswa dan guru dalam bidang komputer yang mudah menarik minat dan perhatian para siswa sesuai teknologi komputer yang berkembang saat ini.

\section{METODE PELAKSANAAN}

Kegiatan pengabdian ini akan dilaksanakan di Kecamatan Medan Denai dan Kecamatan Medan Amplas. Kegiatan pengabdian ini melibatkan mitra yaitu SMK IT Marinah AlHidayah yang berlokasi di Jl. Panglima Denai No 28, Denai dan SMK Swasta Mandiri di Jl. Datuk Kabu No 99 Psr 3 Tembung. Untuk menyelesaikan permasalahan yang dialami oleh mitra, maka metode pendekatan yang kami tawarkan adalah dengan pendekatan individual dan klasikal. Pendekatan klasikal dilakukan pada saat pemberian teori dan latihan kepada para guru dan siswa tentang pengoperasian komputer dan pemberian teori dan pelatihan penggunaan Raspberry Pi. Gambar 1 menunjukkan Fishbone diagram tahapan pelaksanaan pengabdian kepada masyarakat

\section{HASIL DAN PEMBAHASAN}

\subsection{Pemberian Perangkat Pembuatan Running}

Pemberian perangkat Raspberry $\mathrm{Pi}$ dan perangkat pedukungnya untuk praktek pembuatan running text ini telah diberikan pada mitra pertama. Pihak kedua menerima perangkat untuk praktek diberikan disertai penambahan informasi kepada pihak guru dan sekolah mengenai kemampuan Raspberry Pi selain dapat digunakan untuk membuat running text. Hal ini dirasa diperlukan agar Raspberry Pi ini dapat dimaksimalkan kemampuan dan penggunaannya oleh pihak sekolah, selain untuk bahan praktek pembuatan running text.

4.2 Pelaksanaan Kegiatan Pelatihan Pembuatan Running Text

Lanjutan kegiatan pelatihan elearning online telah berhasil dilaksanakan. Para siswa peserta pelatihan dari kedua sekolah mitra masih tetap antusias dalam mengikuti kegiatan pelatihan. Lanjutan kegiatan pelatihan pembuatan running text ini berjalan dengan mencoba contoh kalimat dan bentuk tampilan running text selain yang dijelaskan di dalam modul. Serta diberikan penjelasan dan sedikit contoh manfaat dan kemampuan lain dari raspberry pi. 
Fadly Syahputra, M. et al. Pelatihan Rancang Bangun Peralatan Elektronik...

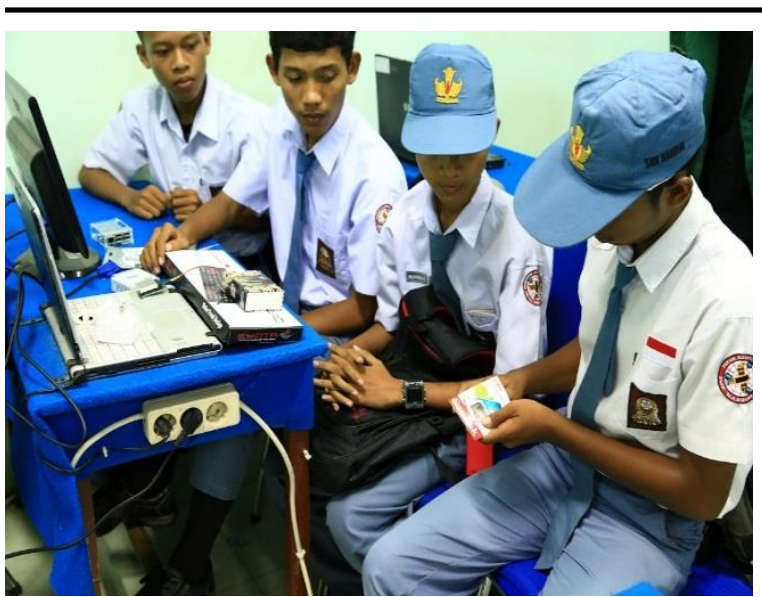

Gambar 4.2.1. Suasana Kegiatan Pengabdian Kepada Masyarakat

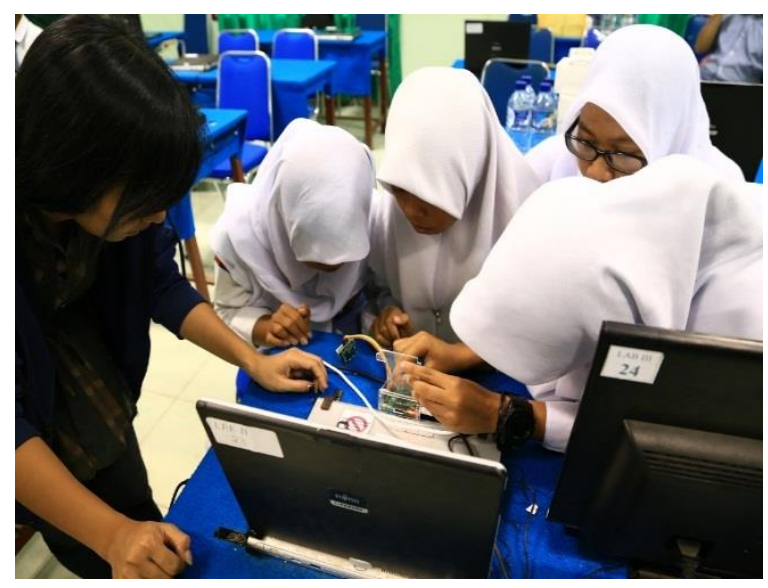

Gambar 4.2.2. Antusiasme Peserta Kegiatan Pengabdian Kepada Masyarakat

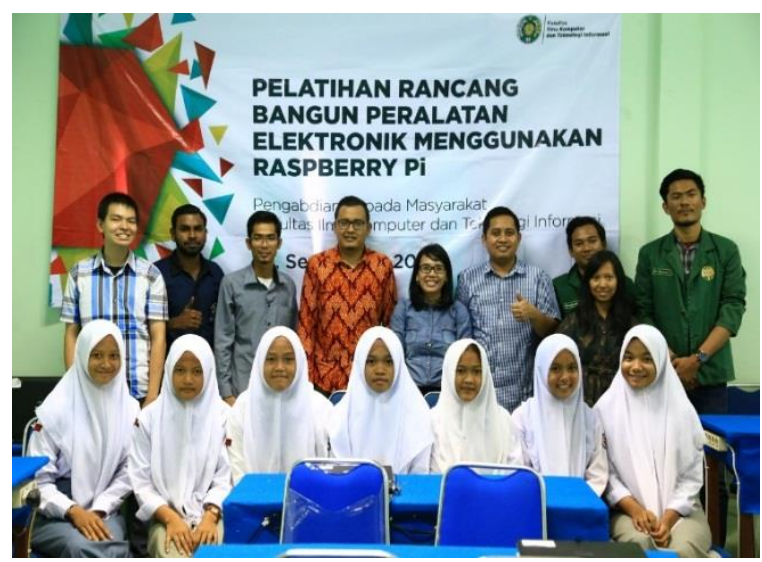

Gambar 4.2.3. Foto Bersama Peserta dan Tim Pengabdian Kepada Masyarakat

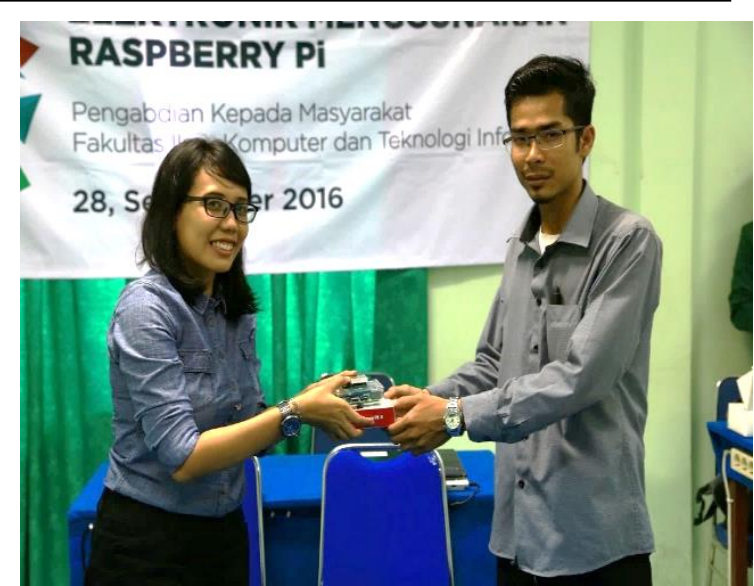

Gambar 4.2.4. Serah terima Raspberry Pi dan Perangkat Pendukungnya

Kegiatan monitoring dan evaluasi terhadap pelaksanaan kegiatan Pengabdian Pada Masyarakat ini telah dilaksanakan pada hari kamis tanggal 10 November 2016. Tim reviewer telah berkunjung ke sekolah mitra dan berdiskusi mengenai proses pelatihan yang telah diikuti dan hasil yang didapatkan oleh sekolah mitra. Sekolah mitra memberikan respon yang postif dengan memaparkan hal-hal dan pengetahuan baru yang telah mereka dapatkan mengenai pemanfaatan elearning online untuk menunjang kegiatan pembelajaran di sekolah.

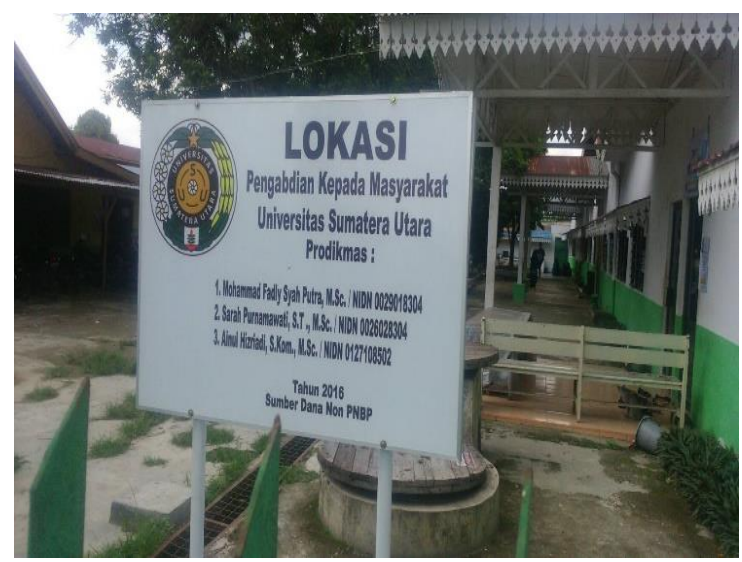

Gambar 4.3.1 Kegiatan Monitoring dan Evaluasi 
Fadly Syahputra, M. et al. Pelatihan Rancang Bangun Peralatan Elektronik...

\section{KESIMPULAN DAN SARAN}

Dari hasil pelaksanaan kegiatan pengabdian pada masyarakat yang telah direalisasikan oleh tim pengabdi, didapatkan kesimpulan sebagai berikut.

1. Perkembangan perangkat elektronik sedemikan berkembangnya sehingga mencapai ukuran yang semakin kecil, ikut diimbangi dengan meningkatnya pemanfaatan perangkat tersebut dalam kurikulum pendidikan di perguruan tinggi dan sekolah menengah atas.

2. Penggunaan perangkat microcontroller seperti Raspberry Pi dapat menjadi satu materi pelajaran dengan praktek yang dapat berguna di kehidupan sehar-hari.

3. Siswa dan Guru membutuhkan lebih banyak materi untuk praktek di laboratorium menggunakan alat-alat seperti Raspberry Pi.

Sedangkan saran yang diperlukan guna meningkatkan hasil dan manfaat kegiatan pengabdian pada masyarakat ini antara lain.

1. Materi praktek menggunakan alat seperti Raspberry Pi sangat menarik minat siswa dan sekolah dalam kegiatan belajar mengajar, sebaiknya dapat diperbanyak jumlah dan modulnya.

2. Mungkin diperlukan tambahan kegiatan ekstrakulikuler oleh pihak sekolah untuk pembelajaran dan praktek-praktek seperti robotika, penggunaan sensor, dan lain-lain.

\section{DAFTAR PUSTAKA}

1. Kebudayaan Direktorat Penelitian Dan Pengabdian Kepada Masyarakat Direktorat Jenderal Pendidikan Tinggi Kementerian Pendidikan Dan Panduan Pelaksanaan Penelitian Dan Pengabdian Kepada Masyarakat di Perguruan Tinggi Edisi IX, 2013

2. Perangin-angin. B, dan Ginting. B, 2013, Penggerak Antena Modem USB Tiga Dimensi Berbasis Mikrokomputer Menggunakan Arduino Uno, Universitas Sumatera Utara, http://repository.usu.ac.id/handle/123 456789/35001, Diakses tanggal 20 Juli 2016.

3. Purwanto. J, dan Fauzi, 2015, Rancang Bangun Alat Pengukur Panjang Jalan Menggunakan Sensor Optocoupler Berbasis Mikrokontroler Atmega8, Universitas Sumatera Utara, http://repository.usu.ac.id/handle/123 456789/46734, Diakses tanggal 20 Juli 2016.

4. http://www.lppm.usu.ac.id 